\title{
Editorial
}

\section{Lipid Metabolism in Plants}

\author{
Hyun Uk Kim \\ Department of Bioindustry and Bioresource Engineering, Plant Engineering Research Institute, \\ Sejong University, Seoul 05006, Korea; hukim64@sejong.ac.kr; Tel.: +82-2-6935-2491
}

Received: 19 June 2020; Accepted: 7 July 2020; Published: 9 July 2020

\begin{abstract}
In plants, lipids function in a variety of ways. Lipids are a major component of biological membranes and are used as a compact energy source for seed germination. Fatty acids, the major lipids in plants, are synthesized in plastid and assembled by glycerolipids or triacylglycerols in endoplasmic reticulum. The metabolism of fatty acids and triacylglycerols is well studied in most Arabidopsis model plants by forward and reverse genetics methods. However, research on the diverse functions of lipids in plants, including various crops, has yet to be completed. The papers of this Special Issue cover the core of the field of plant lipid research on the role of galactolipids in the chloroplast biogenesis from etioplasts and the role of acyltransferases and transcription factors involved in fatty acid and triacylglycerol synthesis. This information will contribute to the expansion of plant lipid research.
\end{abstract}

Keywords: lipid; fatty acid; triacylglycerol; glycerolipid; acyltransferase; transcription factor

\section{Introduction}

Plant lipids are diverse and essential for cells. They are essential for the integrity of cells and organelles by acting as a hydrophobic barrier for the membrane. In addition, lipids are stored in the form of chemical energy in seeds. Furthermore, they act as a signal molecule to regulate cell metabolism [1,2]. The main form of lipid in plants is the glycerolipid in which the carboxyl group of the fatty acid is ester-linked with the hydroxyl group of glycerol. Lipid synthesis involves several organelles in a cell. Fatty acid is synthesized from chloroplasts, and is directly combined with glycerol to become a galactolipid, a major component of the chloroplast membrane, and fatty acids are transferred to the cytoplasm to bind with glycerol in the endoplasmic reticulum (ER) to become a phospholipid of the cell membrane [3]. Between the ER membranes of the seed cells, triacylglycerol (TAG) is synthesized and stored in the oil body [4]. In addition, in the ER of the epidermal cell, fatty acid is transformed into components of cutin and wax, which are lipids of the cuticle layer that prevent water loss [5]. Fatty acid, glycerolipid, and triacylglycerol biosynthesis pathways have been identified through genetic analysis using Arabidopsis mutants [6]. Recently, researchers have been conducting research on the discovery of transcription factors that regulate lipid synthesis [7], the role of galactolipids in photosynthesis [8], cuticle lipid synthesis and transport [9,10], and lipid remodeling during development and stress [11]. To improve the quality and quantitative traits of plant oil in terms of application, studies on the modification of fatty acid composition and the enhancement of oil content are underway $[12,13]$.

This Special Issue introduces the following: the role of galactolipids during the conversion from etioplast to chloroplast under light conditions; Phospholipase A and its association with lignin metabolism; the roles of GPAT9 and PDAT1 involved in TAG synthesis; an integrated review of WRINKELD1 (WRI1), a master transcription factor that regulates TAG synthesis; and a study on TAG synthesis under stress regulation by the MYB96 transcription factor. 


\section{Highlight of Special Issues}

Fujii et al. [14] discussed the role of galactolipids, monogalactosyldiacylglycerol (MGDG), and digalactosyldiacylglycerol (DGDG), in membrane formation in the transition of plastid differentiation from dark to light condition. The process of transforming etioplasts of dark-grown cotyledon to chloroplasts after light expose to the mutants, whose synthesis of galactolipids was inhibited, was observed. It is suggested that galactolipids play a crucial role in the accumulation of chlorophyll biosynthesis and light-harvesting proteins, as etioplasts receive light and transform the internal membranes of prolamellar bodies (PLBs) and prothylakoids (PTs) into thylakoid membranes. This review is an advance that explains why galactolipids exist in photosynthetic plants predominantly present in plastids.

Jang and Lee [15] revealed that Arabidopsis patatin-related PLAIII $\alpha$ affects the lignification of Arabidopsis and polar xylem. Phospholipase A (PLA) consists of two groups in plants. Low-molecular-weight PLA $_{2 S}$ and patatin-related PLA (pPLA) hydrolyze the acyl ester bonds of the glycerolipids, releasing free fatty acids and lysophospholipids [16,17]. The pPLAs participate in a number of cellular processes, such as signal transduction, cell growth regulation, membrane remodeling in response to environmental stress, and lipid metabolism by hydrolyzing membrane glycerolipids [17-19]. In this study, the lignin content was reduced and the ethylene biosynthesis synthetic gene expression was upregulated in the overexpressed PLAIII $\alpha$ in Arabidopsis transgenic plants. The overexpression of PLAIII $\alpha$ in the woody plant poplar downregulated MYB92 and MYB152, the regulators of lignin synthesis. These results suggest that the hydrolysis products of glycerolipids by PLA regulate lignin synthesis. In the future, the discovery of signaling molecules induced by PLA that regulate lignin synthesis is expected.

Yang et al. [20] studied the metabolism of membrane lipid synthesis of Physcomitrella patens, a moss corresponding to early-stage plants during the terrestrial evolution of plants. The haploid cells of P. patens, protonema, and gametophore, have a high content of $65 \%$ of the long-chain polyunsaturated fatty acid (LC-PUFA) and a very-long-chain-PUFA [21-23]. P. patents GPAT9 specifically delivers PUFA from the PUFA-CoA pool, to the hydroxyl group at the $s n-1$ position of glycerol-3-phosphate during glycerolipid synthesis. The PpGPAT9 was introduced into Arabidopsis to further increase the seed oil content by $10 \%$ and further increase the PUFA composition of seed oil by $60 \%$. This suggested that PpGPAT9 can be used to increase the oil content of oilseed seeds through genetic engineering.

Fan et al. [24] studied carbon flux between lipids and sugar. The mutation of ADP-glucose pyrophosphorylase1 (ADG1) does not form a starch. The adg1 mutant does not use starch as an energy source, and thus shows growth inhibition under day/night conditions [25,26]. TAG was synthesized in vegetative tissue by overexpressing phospholipid:diacylglycerol acyltransferase1 (PDAT1) [27] in the adg1 mutant. The fatty acid produced by TAG decomposition in dark conditions was used as an energy source for cellular respiration, thereby reducing the growth inhibition of the adg1 mutant under day/night conditions. In the future, in-depth research on carbon remobilization between TAG and starch is expected.

Lee et al. [28] suggested that the MYB96 transcription factor not only regulates the oil content during seed development [7], but also controls the synthesis of TAG in drought stress in vegetative tissue leaves. TAG accumulation was very high in Arabidopsis seedlings where MYB96 was constitutively overexpressed. MYB96 is induced by ABA to directly regulate PDAT1 and indirectly regulate diacylglycerol acyltransferase1 (DGAT1), the last two enzyme genes of TAG synthesis, to induce TAG synthesis in leaves. TAG accumulation in vegetative tissue under stress will contribute to the optimization of energy metabolism and the sequestering of toxic fatty acids degraded by membrane lipids. Research on the metabolism of TAG under stresses is a research area that has recently been focused on.

Kong et al. [29] reviewed the integrated regulatory mechanism of WRINKLED1, the primary transcriptional regulator of plant oil biosynthesis. In 1998, Benning's lab first reported that the wri1-1 mutant is a transcription factor that regulates seed oil content due to finding that the oil content is 
reduced by $80 \%$ compared to wild type seeds [30]. Subsequently, it was found that WRI1 regulates many genes involved in glycolysis and fatty acid biosynthesis at the level of transcription regulation [31]. Recently, it was found that WRI1 regulates target gene expression through interaction with Mediator Subunit 15 (MED15) [32] and BTB/POZMATH (BPM) [33] regulators, or through phosphorylation by kinase KIN10 [34]. WRI has been studied as a candidate transcription factor that can be used in the development of biotech crops to improve oil production [35]. The creation of the WRI1 new allele with enhanced activity through targeted base editing in the regulatory domain of WRI1 suggests the possibility for crop development with enhanced oil content.

Funding: This work was supported by a grant from the New Breeding Technologies Development Program (Project No. PJ01532401), Rural Development Administration, Korea.

Acknowledgments: I would like to thank all colleagues that contributed to this Special Issue and the editorial office for their helpful support during the compilation of this issue.

Conflicts of Interest: The author declares no conflict of interest.

\section{References}

1. Ohlrogge, J.; Browse, J. Lipid biosynthesis. Plant Cell 1995, 7, 957-970.

2. Li-Beisson, Y.; Shorrosh, B.; Beisson, F.; Andersson, M.X.; Arondel, V.; Bates, P.D.; Baud, S.; Bird, D.; Debono, A.; Durrett, T.P.; et al. Acyl-lipid metabolism. Arab. Book 2013, 11, e0161. [CrossRef]

3. Chapman, K.D.; Ohlrogge, J.B. Compartmentation of triacylglycerol accumulation in plants. J. Biol. Chem. 2012, 287, 2288-2294. [CrossRef]

4. Chapman, K.D.; Aziz, M.; Dyer, J.M.; Mullen, R.T. Mechanisms of lipid droplet biogenesis. Biochem. J. 2019, 9, 1929-1942. [CrossRef] [PubMed]

5. Yeats, T.H.; Rose, J.K. The formation and function of plant cuticles. Plant Physiol. 2013, 163, 5-20. [CrossRef] [PubMed]

6. Wallis, J.G.; Browse, J. Mutants of Arabidopsis reveal many roles for membrane lipids. Prog. Lipid Res. 2002, 41, 254-278. [CrossRef]

7. Lee, H.G.; Kim, H.; Suh, M.C.; Kim, H.U.; Seo, P.J. The MYB96 transcription factor regulates triacylglycerol accumulation by activating DGAT1 and PDAT1 expression in Arabidopsis seeds. Plant Cell Physiol. 2018, 59, 1432-1442. [CrossRef] [PubMed]

8. Li, H.-M.; Yu, C.-W. Chloroplast galactolipids: The link between photosynthesis, chloroplast shape, jasmonates, phosphate starvation and freezing tolerance. Plant Cell Physiol. 2018, 59, 1128-1134. [CrossRef] [PubMed]

9. Fich, E.A.; Segerson, N.A.; Rose, J.K. The plant polyester cutin: Biosynthesis, structure, and biological roles. Annu. Rev. Plant Biol. 2016, 29, 207-233. [CrossRef]

10. Lee, S.B.; Suh, M.C. Advances in the understanding of cuticular waxes in Arabidopsis thaliana and crop species. Plant Cell Rep. 2015, 34, 557-572. [CrossRef]

11. Yang, Y.; Benning, C. Functions of triacylglycerols during plant development and stress. Curr. Opin. Biotechnol. 2018, 49, 191-198. [CrossRef] [PubMed]

12. Lee, K.R.; Chen, G.Q.; Kim, H.U. Current progress towards the metabolic engineering of plant seed oil for hydroxy fatty acids production. Plant Cell Rep. 2015, 34, 603-615. [CrossRef] [PubMed]

13. Vanhercke, T.; Dyer, J.M.; Mullen, R.T.; Kilaru, A.; Rahman, M.M.; Petrie, J.R.; Green, A.G.; Yurchenko, O.; Singh, S.P. Metabolic engineering for enhanced oil in biomass. Prog. Lipid Res. 2019, 74, 103-129. [CrossRef]

14. Fujii, S.; Wada, H.; Kobayashi, K. Role of Galactolipids in plastid differentiation before and after light exposure. Plants 2019, 8, 357. [CrossRef] [PubMed]

15. Jang, J.H.; Lee, O.R. Patatin-related phospholipase AtpPLAIII $\alpha$ affects lignification of xylem in Arabidopsis and hybrid poplars. Plants 2020, 9, 451. [CrossRef] [PubMed]

16. Lee, O.R.; Kim, S.J.; Kim, H.J.; Hong, J.K.; Ryu, S.B.; Lee, S.H.; Ganguly, A.; Cho, H.T. Phospholipase A2 is required for PIN-FORMED protein trafficking to the plasma membrane in the Arabidopsis root. Plant Cell 2010, 22, 1812-1825. [CrossRef]

17. Scherer, G.F.E.; Ryu, S.B.; Wang, X.; Matos, A.R.; Heitz, T. Patatin-related phospholipase A: Nomenclature, subfamilies and functions in plants. Trends Plant Sci. 2010, 15, 693-700. [CrossRef] 
18. Wang, X. Plant phospholipases. Annu. Rev. Plant Physiol. Plant Mol. Biol. 2001, 52, 211-231. [CrossRef]

19. Holk, A.; Rietz, S.; Zahn, M.; Quader, H.; Scherer, G.F.E. Molecular identification of cytosolic, patatin-related phospholipases A from Arabidopsis with potential functions in plant signal transduction. Plant Physiol. 2002, 130, 90-101. [CrossRef]

20. Yang, S.U.; Kim, J.; Kim,H.; Suh, M.C. Functional characterization of Physcomitrella patens glycerol-3-phosphate acyltransferase 9 and an increase in seed oil content in Arabidopsis by its ectopic expression. Plants 2019, 8, 284. [CrossRef]

21. Beike, A.K.; Jaeger, C.; Zink, F.; Decker, E.L.; Reski, R. High contents of very long-chain polyunsaturated fatty acids in different moss species. Plant Cell Rep. 2014, 33, 245-254. [CrossRef] [PubMed]

22. Grimsley, N.H.; Grimsley, J.M.; Hartmann, E. Fatty acid composition of mutants of the moss Physcomitrella patens. Phytochemistry 1981, 20, 1519-1524. [CrossRef]

23. Resemann, H.C.; Lewandowska, M.; Gomann, J.; Feussner, I. Membrane lipids, waxes and oxylipins in the moss model organism Physcomitrella patens. Plant Cell Physiol. 2019, 60, 1166-1175. [CrossRef] [PubMed]

24. Fan, J.; Zhou, C.; Yu, L.; Li, P.; Shanklin, J.; Xu, C. Diversion of carbon flux from sugars to lipids improves the growth of an Arabidopsis starchless mutant. Plants 2019, 8, 229. [CrossRef] [PubMed]

25. Lin, T.P.; Caspar, T.; Somerville, C.; Preiss, J. Isolation and characterization of a starchless mutant of Arabidopsis thaliana (L.) lacking ADPglucose pyrophosphorylase activity. Plant Physiol. 1988, 86, 1131-1135.

26. Caspar, T.; Huber, S.C.; Somerville, C. Alterations in growth, photosynthesis, and respiration in a starchless mutant of Arabidopsis thaliana (L.) deficient in chloroplast phosphoglucomutase activity. Plant Physiol. 1985, 79, 11-17. [CrossRef]

27. Fan, J.; Yan, C.; Zhang, X.; Xu, C. Dual role for phospholipid: Diacylglycerol acyltransferase: Enhancing fatty acid synthesis and diverting fatty acids from membrane lipids to triacylglycerol in Arabidopsis leaves. Plant Cell 2013, 25, 3506-3518. [CrossRef]

28. Lee, H.G.; Park, M.-E.; Park, B.Y.; Kim, H.U.; Seo, P.J. The Arabidopsis MYB96 transcription factor mediates ABA-dependent triacylglycerol accumulation in vegetative tissues under drought stress conditions. Plants 2019, 8, 296. [CrossRef]

29. Kong, Q.; Yuan, L.; Ma, W. WRINKLED1, a "master regulator" in transcriptional control of plant oil biosynthesis. Plants 2019, 8, 238. [CrossRef]

30. Focks, N.; Benning, C. wrinkled1: A novel, low-seed-oil mutant of Arabidopsis with a deficiency in the seed-specific regulation of carbohydrate metabolism. Plant Physiol. 1998, 118, 91-101. [CrossRef]

31. Ruuska, S.A.; Girke, T.; Benning, C.; Ohlrogge, J.B. Contrapuntal networks of gene expression during Arabidopsis seed filling. Plant Cell 2002, 14, 1191-1206. [CrossRef] [PubMed]

32. Kim, M.J.; Jang, I.C.; Chua, N.H. The mediator complex MED15 subunit mediates activation of downstream lipid-related genes by the WRINKLED1 transcription factor. Plant Physiol. 2016, 171, 1951-1964. [CrossRef]

33. Chen, L.; Lee, J.H.; Weber, H.; Tohge, T.; Witt, S.; Roje, S.; Fernie, A.R.; Hellmann, H. Arabidopsis BPM proteins function as substrate adaptors to a CULLIN3-based E3 ligase to affect fatty acid metabolism in plants. Plant Cell 2013, 25, 2253-2264. [CrossRef] [PubMed]

34. Zhai, Z.; Liu, H.; Shanklin, J. Phosphorylation of WRINKLED1 by KIN10 results in its proteasomal degradation, providing a link between energy homeostasis and lipid biosynthesis. Plant Cell 2017, 29, 871-889. [CrossRef] [PubMed]

35. Liu, J.; Hua, W.; Zhan, G.; Wei, F.; Wang, X.; Liu, G.; Wang, H. Increasing seed mass and oil content in transgenic Arabidopsis by the overexpression of wril-like gene from Brassica napus. Plant Physiol. Biochem. 2010, 48, 9-15. [CrossRef]

(C) 2020 by the author. Licensee MDPI, Basel, Switzerland. This article is an open access article distributed under the terms and conditions of the Creative Commons Attribution (CC BY) license (http://creativecommons.org/licenses/by/4.0/). 